\title{
レーザー医療応用
}

\author{
渥美 和彦
}

\section{Medical Application of Laser}

\author{
Kazuhiko ATSUMI $^{\dagger}$
}

(Received December 9, 2009)

\begin{abstract}
Development of laser application in medicine since the discovery of a ruby laser in 1960 is reviewed. Various types of lasers have widely been used not only for diagnostics of disease but as tools in therapy. Significance of medical application of lasers will expand further under the support of progress in electronics, material science, mechatronics and communication technologies.
\end{abstract}

Key Words: Laser therapy, Medical laser application

\section{1.はしがき}

1960年, Maimanがルビーレーザーの発振に成功し， レーザー光応用の幕はひらかれた。レーザー光は, (1)単 色性, (2)指向性, (3)収束性, (4)高輝度などの優れたコ ヒーレントな光線であり, 従来の非コヒーレントな光線 では考えられない多くの特色をもっている.

レーザー発見の翌年には，ルビーレーザーを利用した 眼底の網膜剥離に対する光凝固治療への応用が始められ るようになった。レーザーの医学への応用の進歩は, 1963年～1975年の第一期， 1975年～1985年までの第二 期，それ以後の第三期の3つに分けることができる.

第一期においては, ルビー, $\mathrm{He}-\mathrm{Ne}$, あるいはアルゴ ンなどのレーザーが使用されて, 高分子, タンパク質, 酵素, 細胞, あるいは生体組織などに対してレーザー光 を照射し，レーザーによる生体反応の基礎的研究のデー 夕が集積された時代であったと言える。眼科領域では, 早期からルビーレーザーが臨床に試みられたが，1960年 〜1970年代のレーザーの医学応用の最大の関心の一つ は，悪性腫瘍への効果であったと言える.

第二期においては， $\mathrm{CO}_{2}$ レーザーの開発が進み，無血 外科手術用メスとして, 臨床各分野に広がった。 また, $\mathrm{Nd}: \mathrm{YAG}$ レーザーやアルゴンレーザーが光ファイバの中 を通ることから内視鏡と組み合わされることにより, 独 自の治療法も開発されるようになった。一方, レーザー 光の優れた特性を利用したレーザー診断法は, 画期的な 精密診断を可能にしたと言える。光増感物質を利用した 光化学治療 $(\mathrm{PDT})$ やレーザー医学の診断への応用は,
レーザーの高エネルギーの利用から低エネルギーの利用 への道を開いた。

第三期には，低エネルギーを利用した生体刺激作用へ のレーザーの応用が新しい分野を開くことになった。さ らに，パルスレーザーの非熱作用による結石破壊への応 用が始まったが，これもレーザーの新しいエネルギー利 用である。

\section{2. 医学に利用されるレーザー}

レーザーはパルス波と連続波を発振する。その発振波 長はレーザー材料により, 固有のものであるという特色 を有している。すなわち、レーザー源の物質が決まる と, それから発振されるレーザー光の波長が決まるとい うことになる。

医学応用のレーザーは, 固体, 気体, 半導体, 色素 (液体)といった現在までに開発されたレーザーのほとん どすべてのものが利用されており, 発振されるレーザー 光の波長は, 紫外から赤外の領域をカバーしている (Table 1).

医学の治療用としては，初期においてはルビー，アル ゴン，あるいはクリプトンが中心であり，最近までは炭 酸ガス $\left(\mathrm{CO}_{2}\right), \mathrm{Nd}: \mathrm{YAG}$, アルゴンの3つが中心であっ た。ささにその後, 半導体や色素レーザーが治療に応用 されたが，最近は，ホロミウム，エキシマレーザーの利 用も始められ，自由に波長を選択しうる自由電子レー ザーの医学的応用も各国で検討し始められている。一 方, 医学の検査, あるいは診断用としては, He-Neが利

†東京大学 名誉教授

${ }^{\dagger}$ Professor Emeritus, University of Tokyo 
Table 1 Lasers used in various medical purpose.

\begin{tabular}{|c|c|c|c|c|c|c|}
\hline & 種類 & 発振様式 & 波長 $(\AA)$ & $\begin{array}{c}\text { 連続出力 } \\
(\mathrm{W})\end{array}$ & $\begin{array}{c}\text { ピーク出力 } \\
(\mathrm{MW})\end{array}$ & 用途 \\
\hline \multirow{6}{*}{ 固 } & ルビー & $\begin{array}{l}\text { パルス } \\
\text { Qスイッチ }\end{array}$ & $\begin{array}{c}6,943 \\
3,472 \\
\text { (第 } 2 \text { 高調波) }\end{array}$ & 2.4 & 数十 & $\begin{array}{l}\text { 眼科用光凝固装置(小出力), } \\
\text { 皮膚·腫瘍への照射, 細胞微小外科, } \\
\text { ホログラフィー光分光分析 }\end{array}$ \\
\hline & Nd:ガラス & $\begin{array}{l}\text { パルス } \\
\text { Qスイッチ }\end{array}$ & $\begin{array}{c}10,600 \\
5,300 \\
(\text { 第 } 2 \text { 高調波 })\end{array}$ & & 100 & $\begin{array}{l}\text { 皮盧・脳腫癌への照射, 発光分光分析, } \\
\text { 色素レーザ起 }\end{array}$ \\
\hline & Nd:YAG & 連 続 波 & \begin{tabular}{|c|}
10,610 \\
5,300 \\
(第 2 高調波)
\end{tabular} & 105 & 10 & $\begin{array}{l}\text { 内視鏡的光凝固装置, 外科手術用 } \\
\text { 上ーザーメス } \\
\text { (肝臓外科, 脳神経外科など })\end{array}$ \\
\hline & Ho:YAG & パルス & 2060 & & & 歯科用, 結石破壊用 \\
\hline & Er:YAG & パルス & 2940 & & & " \\
\hline & \begin{tabular}{|l|} 
アレクサン \\
ドライト
\end{tabular} & パルス & 7550 & & & 美容(脱毛), 整形 \\
\hline \multirow{11}{*}{$\begin{array}{l}\text { 気 } \\
\text { 体 }\end{array}$} & $\mathrm{He}-\mathrm{Ne}$ & 連 続 波 & $\begin{array}{c}6,328 \\
11,500 \\
33,900 \\
\end{array}$ & $0.01 \sim 0.1$ & & $\begin{array}{l}\text { 写真, 透過照明, ホログラフィー, } \\
\text { 流速計, 細胞微小外科, 鍼炎術 }\end{array}$ \\
\hline & $\mathrm{He}-\mathrm{Cd}$ & 連 続 波 & $\begin{array}{l}3,250 \\
4,416 \\
\end{array}$ & $0.01 \quad 0.06$ & & $\begin{array}{l}\text { 癌の治療 } \\
\text { 蛍光法, 速計, 顕微鏡 }\end{array}$ \\
\hline & $\mathrm{Ar}^{+}$ & 連 続 波 & $\begin{array}{l}4,579 \sim \\
5,145\end{array}$ & 22 & $10^{-4}$ & $\begin{array}{l}\text { 眼科用光凝固装置, レーザーメス, } \\
\text { 細胞微小科, ホログラフィー, } \\
\text { 光化学療法 }\end{array}$ \\
\hline & $\mathrm{Kr}$ & 連 続 波 & $4,762 \sim 6,471$ & 6 & & ホログラフィー, 眼科用光凝固装置 \\
\hline & $\mathrm{CO}_{2}$ & 連 続 波 & $\begin{array}{c}92,800 \\
96,200 \\
106,000\end{array}$ & $\begin{array}{l}\text { 堼じ切り } 30 \\
\text { 低速フロー } \\
1 \sim 1,000 \\
\text { 高速フロー } \\
1 \sim 20,000\end{array}$ & $10^{-1}$ & $\begin{array}{l}\text { 外科手術用レーザーメス, } \\
\text { (一般外科, 脳神経外科, 耳鼻科, } \\
\text { 産婦人科, 蒌科など) }\end{array}$ \\
\hline & $\mathrm{CO}$ & 連 続 波 & 53,000 & $20 \sim 50$ & & 外科手術用レーザーメス \\
\hline & $\mathrm{Cu}$ & 連 続 波 & 5,000 & $0.1 \sim 5$ & & $\begin{array}{l}\text { 生物学的研究(癌) } \\
\text { 内視鏡的光凝固装置 }\end{array}$ \\
\hline & $\mathrm{N}_{2}$ & 準連続波 & 3,371 & 0.25 & $10^{-2} \sim 10^{-1}$ & 生物学的研究(癌) \\
\hline & $\mathrm{Xe}$ & 連 続 波 & $4,603 \sim 6,270$ & $0.1 \sim 0.5$ & & 生物学的研究 (癌) \\
\hline & $\mathrm{Ne}$ & 連 続 波 & 3,324 & 0.25 & & 生体計測, 診断 \\
\hline & エキシマ & 連 続 波 & $1930 \sim 3530$ & & & 角膜切削 (眼科), 血管内形成術 \\
\hline $\begin{array}{l}\text { 半 } \\
\text { 噵 } \\
\end{array}$ & $\mathrm{Ga}-\mathrm{As}$ & 準連続波 & 8,400 & $1 \sim 20$ & & $\begin{array}{l}\text { 低エネルギー利用(創傷治癒，痛み抑制) } \\
\text { レーザー杖，銊炎術 }\end{array}$ \\
\hline \multirow{2}{*}{$\begin{array}{l}\text { 液 } \\
\text { 体 }\end{array}$} & \multirow{2}{*}{ 色素 } & 連 続 波 & $3.62 \sim 10.20$ & $0.01 \sim 1$ & & \multirow{2}{*}{$\begin{array}{l}\text { 生物学的研究 } \\
\text { 癌の治療 }\end{array}$} \\
\hline & & パルス波 & $3.11 \sim 12.85$ & & $0.001 \sim 1$ & \\
\hline
\end{tabular}

用されることが多い.

レーザー光は, 従来の光にはない優れた特性を利用す ることによって, 従来は不可能であった診断や治療を可 能にしている。 その医学への応用は広く(Table 2)のごと く, 治療, 診断, その他とに分類することができる.

\section{3. レーザー医学の学会と会議}

1965年に米国のボストンで第1回のレーザー医学研究 会 (1st Annual Biomedical Laser Conference of Laser Medical Research)開かれ，レーザーの腫瘍への効果が発表さ れた。その後、レーザー医学あるいは医用レーザー専門 の国際的な研究会や会議がもたれるようになったが，本 格的に国際的な会合が開かれるようになったのは，1975 年以降である.

第4回国際レーザー外科会議は，1981年，東京におい て筆者らにより開かれ，内容も外科に関するレーザーの 応用から, 広く, 内科, 診断学にまで拡大されて, 参加 者は 800 人, 発表論文は 292 題と, 質量ともに国際会議は 大きく飛躍することとなった。
この正統な国際会議の他に, 光化学レーザー療法, Nd:YAGレーザー医学, レーザー低エネルギーの医学応 用などの国際会議が米国，イタリア，西ドイツなどで開 かれた。また，米国，フランス，イタリア，日本などの 各国においても盛んにレーザー医学会議がひらかれるよ うになった。

なお，中国(1982年)，韓国(1983年)，台湾(1984年) と, 東南アジアにおいても, 次々と各国の学会が組織さ れ，学会交流活動も盛んになってきている。1985年に は, アジア・太平洋レーザー医学会議が設立され，第1 回の会議が東京において開催された.

\section{4. わが国におけるレーザー医学の進歩}

わが国のレーザー医学の研究は，1965年すでに筆者ら の東大グループにより，ルビーレーザーを使用した基礎 的研究が進められた。 その後, 医用高出力ルビーレー ザー装置が開発され，1967年，皮膚癌へのレーザー治療 の本邦第一例が試みられている。その後, ルビー, $\mathrm{CO}_{2}, \mathrm{He}-\mathrm{Ne}$, アルゴン, Nd:YAGの各レーザーの開発お 
Table 2 Medical laser application (Kazuhiko Atsumi, Yasuhisa Sakurai, 1978).

\begin{tabular}{|c|}
\hline 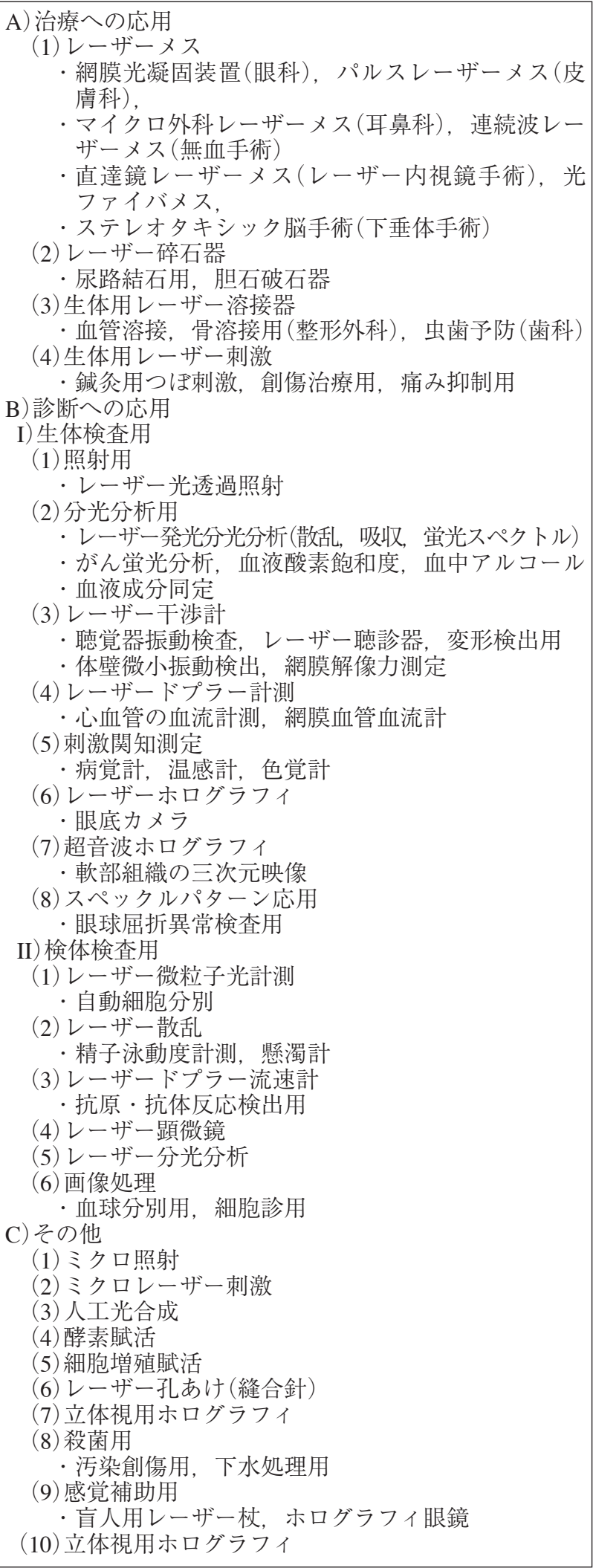 \\
\hline
\end{tabular}

よび利用により, 基礎的, 臨床的研究がわが国の各地に おいて行われた. さらにその後, 光化学治療, $\mathrm{CO}_{2}$ レー

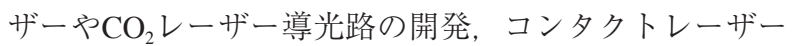
プローベ，低エネルギーレーザー治療，血管吻合や骨折 治療，心臓血管系への応用など，多方面にわたりレー
ザーの治療への応用が拡がった。

一方，医学の検査・診断の分野におけるレーザーの利 用も1960年代の後半に，筆者ら東大グループにより進め られた。すなわち、レーザードップラー血流計測，レー ザー発光分光分析，超音波ホログラフィの開発などであ る.

その後, レーザースペックルパターン，光ファイバに よるレーザードップラー血流計測, 生体組織のレーザー スペックル分析, 自動生体細胞分離, レーザー光励起蛍 光癌計測などのユニークな研究が行われた。さらに, レーザーホログラフィ，レーザー回折法なども利用され ている.

\section{5. レーザー医学の三大成人病への挑戦}

レーザー医学は，レーザーを生体に作用させる，ある いは医学に利用することによって, 人類の診療のみなら ず，健康維持，疾病予防，リハビリテーション，老化防 止などに広く役立つものである。日本人の 3 大死因は, 癌, 心臓病および脳血管障害であり, これらの疾病の克 服のための挑戦は、レーザー医学にとって最も重要な課 題であろう.

\section{1 心臓病のレーザー診断およびレーザー治療}

現在，心臓病のレーザー診断の方法としては，(1)超音 波ホログラフィ，(2)X線ホログラフィ，(3)レーザードッ プラー血流計測, (4)レーザー発光分光分析などの方法が ある。これらのうち，超音波ホログラフィの発展のため には，今後，超音波透過像の基礎的研究，ホログラム材 料の開発および映像の画質向上のための処理の研究が必 要である。X線ホログラフィは将来その応用が考えられ るものである.

レーザードップラー血流計測は, 光ファイバの開発, 局所誘導法などの基礎的研究により，血管および心臓系 の多くの分野に利用される可能性がある。レーザー発光 分光分析は, 最近, ドイツにおいて一段と感度を向上さ せた装置が開発され，従来測定が不可能であった新しい 元素の半定量分析が可能になったとのことであるが，今 後，装置の簡便化が重要な課題となろう.

心臓病の治療としては, (1)血管内レーザー内視鏡によ る心臓弁手術, (2)レーザー光穿通による心筋内血管再 生, (3)レーザー光による狭窄冠動脈の開存, (4)レーザー 光による洞房結節および刺激伝導路への刺激などがあげ られる。

これらの中，(1)ついては，動物実験が行われ，その 可能性が検討されている。（2)については，米国およびわ が国において十数例の臨床応用が試みられ，(3)について は，開胸下および非開胸下での臨床例が米国において数 百例が報告されたが，術後に狭窄が起こることが判り， その後, 臨床が中断されている，(4については，世界に おいて臨床例が続けられている。 
5.2 癌に対するレーザー診断およびレーザー治療 主な癌のレーザー診断としては, (1)レーザー光スペク トル診断法および(2)レーザー光癌蛍光法などがあげられ る.レーザー光スペクトル診断法は，レーザー光により 生体組織の反射, 吸収, 散乱, 蛍光スペクトルを分析す るもので, 基礎的研究, 各種波長の発振レーザー, さら にそれらの光を導光する光ファイバの開発が重要であ る.レーザー光癌蛍光法は, 癌の部位がアルゴンレー ザー光の励起により蛍光を発生するというもので, 簡便 できわめて応用の多い方法である。現在, 必ずしもすべ ての悪性腫瘍にのみ蛍光が発生するわけではなく, 今 後, 蛍光発生のメカニズムの解明が重要である.

癌の治療の方法としては, レーザー光の高エネルギー を利用して癌を破壊(気化・蒸散・凝固)する方法と, レーザー光の低エネルギーを利用して光化学療法を行う 方法とがある。前者においては, 今後, レーザーの波 長, エネルギー密度, 作用時間などと生体組織の相互作 用の基礎的研究や周囲損傷部を検知し防護する方法, あ るいは制癌のソフトウェアのガイドラインなどが重要で あろう。後者においては, 光増感物質の励起による制癌 作用機序の解明，および新しい, さらに有効で副作用の 少ない, 腫瘍に選択的に集積する光増感物質の開発が必 須であり，医用波長選択性のレーザーの開発も重要とな ろう。

\section{3 脳卒中のレーザー治療}

脳卒中の治療法としては, (1)脳内出血部位の止血およ び修復, (2)レーザー光刺激による壊死巣の吸収および拡 大の防止, (3)脳内血管の動脈瘤治療(経血管), (4)四肢麻 痺筋のレーザー刺激によるリハビリテーションなどがあ げられる.

これらの基本としては, レーザー光の細胞活性化に対 する，酵素レベルあるいは分子レベルでのメカニズムの 基礎的解明が必要となろう.

\section{6. 未来のレーザー医学}

現在までに開発された医用レーザー技術としては，下 記の(1)から (13)までがあげられて, その一部は臨床に も応用されつつある。（14）および(15) は将来の夢として 開発が期待されている.

(1) 携帯用 (出力 $20 \mathrm{~W}$ ) 超小型 $\mathrm{CO}_{2}$ レーザーメス

(2) 癌治療用紫外線レーザー $\left(\mathrm{N}_{2}, \mathrm{He}-\mathrm{Cd}\right.$, エキシマな ど) メ久

(3) 波長可変の医用色素レーザー装置

(4)レーザー鍼治療用半導体レーザー

(5) 医用エキシマレーザー血管外科用装置

(6)紫外線より遠赤外線までの各種の領域のレーザー光 を伝達する光ファイバ(無毒性)
（7）光ファイバによる $\mathrm{CO}_{2}$ レーザー, Nd:YAGレーザー, アルゴンレーザーとの組み合わせ装置と中央管理手 術室設計

(8) 高感度，小型レーザー発光分光分析装置

（9）レーザー散乱，吸収スペクトル分光分析装置

(10)レーザー散乱污濁度測定装置

(11)携帯用簡便型レーザードップラー血流計測装置

(12) レーザー蛍光癌診断装置

(13) 医用超音波ホログラフイ装置

(14) 自由電子レーザー

(15)X線レーザー

ここで, 遠未来の夢も含めてレーザー医学の未来を考 えてみると，次のような項目が期待されよう。これらの ほとんどのものは，原理的には実現可能のものである が，その開発のためにはレーザー技術の他にメカトロニ クス, マイクロエレクトロニクス, 光技術, 高分子材料 あるいは超伝導など周辺の高度の技術の支援を必要とす ることとなろう。

（1）レーザー内視鏡による全身の組織の非侵襲，無血手 術の実現

（2）レーザー分光や蛍光による各種病変や疾患, 癌など の診断

(3)モノクローナル抗体とレーザー自動細胞識別による 各種疾患や癌診療

(4) 癌の選択的治療

(5) レーザー光化学作用による癌リンパ線郭清

(6) 光ファイバレーザーによる血管内および心臓手術

（7）超微小外科による細胞内手術

(8) 波長可変レーザーによる細胞内代謝の解明

(9)免疫拒絶反応の予知

(10) レーザー微弱発光による生体内自動酸化や酵素過程 の解明

(11) 超音波, X線ホログラフィによる生体臓器のオンラ イン三次元映像化

（12）レーザー鍼治療による健康増進や痛みの抑制

(13)X線レーザーによる遺伝子工学

（14）光ファイバレーザー通信による医療情報や画像の伝 送

(15) 光コンピュータ (レーザー)を利用した高密度, 高速 の医療データバンクの実現

（16）レーザー診療を総合化したレーザー病院の実現

\section{7. 結 び}

レーザー医学は，従来は不可能であった診断や治療を 可能にするという点で意義がある。今後，レーザー技術 の進歩とその医学への応用により，医学の研究や医療の 分野のみならず，医療経済の分野にも革命が起こる可能 性がある。 